Open Access

Res. Agric. Livest. Fish.

Research Article

Vol. 2, No. 3, December 2015: 411-417

\title{
IMPACT OF DRUG ADDICTION ON SOCIAL ENVIRONMENT FOCUSED IN MYMENSINGH DISTRICT
}

\section{Md. Azharul Islam*, Md. Towfael Hossen, Md. Khaled Hossain, Kaniz Fatima and Marzia Khatun}

Department of Environmental Science, Faculty of Agriculture, Bangladesh Agricultural University, Mymensingh-2202, Bangladesh

*Corresponding author: Md. Azharul Islam; E-mail: maislam@bau.edu.bd

\section{ARTICLE INFO ABSTRACT}

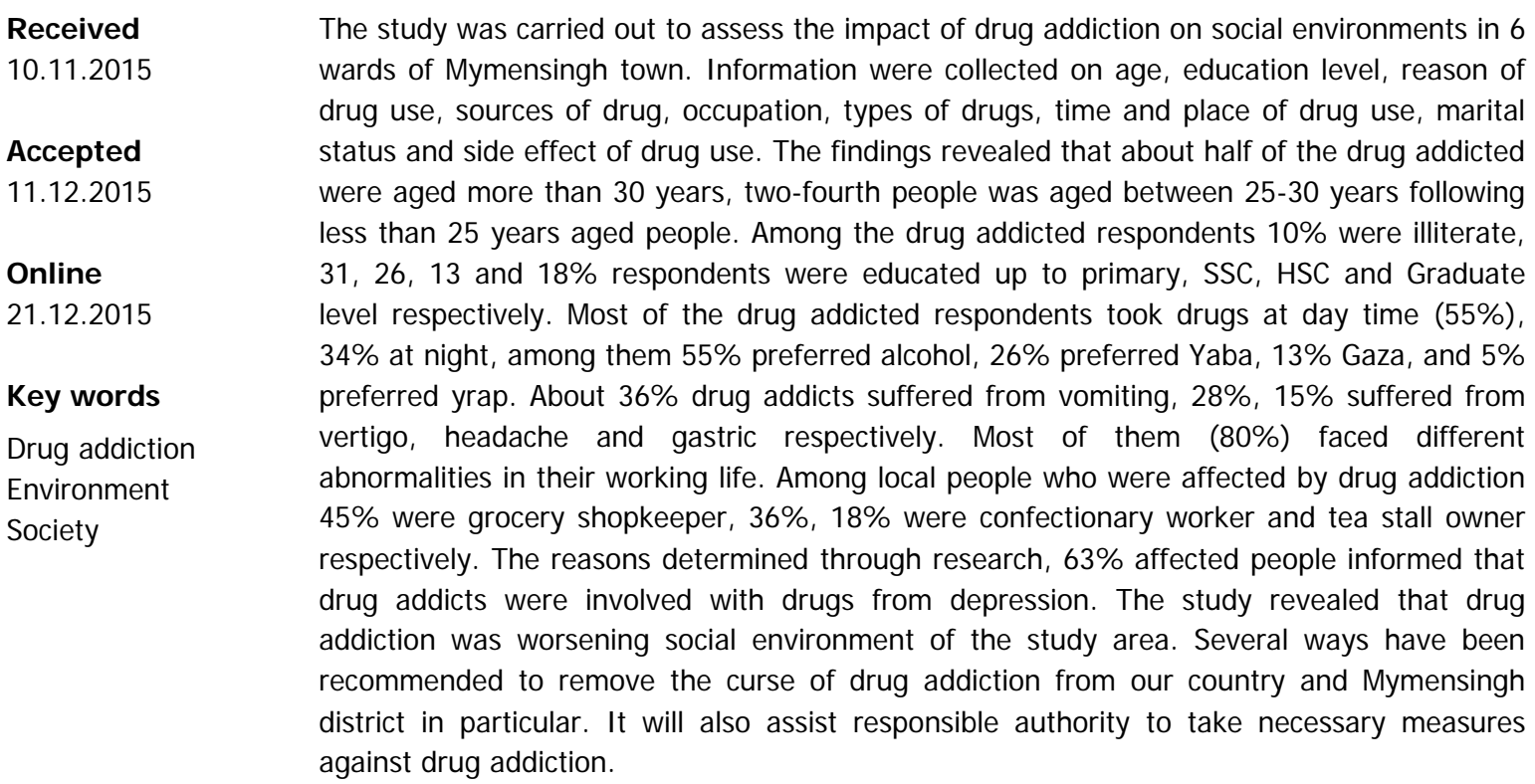

To cite this article: Islam M A, M T Hossen, M K Hossain, K Fatima and M Khatun, 2015. Impact of drug addiction on social environment focused in Mymensingh district. Res. Agric. Livest. Fish. 2 (3): 411-417.

This is an open access article licensed under the terms of the Creative Commons Attribution 4.0 International License

www.agroaid-bd.org/ralf, E-mail: editor.ralf@gmail.com 


\section{INTRODUCTION}

Drug addiction has become a major social problem in Bangladesh. In a developing country like Bangladesh, incidence of drug addiction has been increasing day by day. It was a problem of developed countries beforehand, now it is one of the important social problems of our country. It seems our country has been trapped by this social problem. Drug addiction hampers the mental and physical strengths of human being. Drug use affects virtually every organ system of the body, from the central nervous system to the cardiovascular, endocrine, respiratory, and immune systems (UNODC, 2003).

Bangladesh is located between the Golden Crescent to the west, comprising Afghanistan, Pakistan, Iran and Golden Triangle to the east, comprising Myanmar, Laos, Vietnam and Thailand. Afghanistan remains the largest cultivator of illicit opium poppy in the world, accounting for approximately $87 \%$ of illicit opium worldwide and amounts to one third of its GDP (Gross Domestic Product). Myanmar is the world's second largest producer of illicit opium with annual production of 1090 metric tons (Amin, 2007). The most commonly used drugs are cannabis (equivalent to ganja in Indian subcontinent), phensidyl (cough syrup containing codeine), sedatives and heroin. Other drugs, namely buprenethazine (tamagesic-an opiate), diazepam, promethazine (phenargan), synthetic opiates such as pethidine (meperidine), pentazocine and morphine are also commonly injected drugs in South Asian countries including Bangladesh (Ray, 1998; Reid, 2002; UNODC, 2003; Ikfat, 2007). Due to the improved and easy transport facilities drugs are being available easily around the world (UNODC, 2003). In recent years, drug addiction has been significantly increased in Mymensingh district (Dip, 2010). This agent of human devastation has spread its tentacles in Mymensingh and also in our country. Every intelligent and conscious person in the society is alarmed by the present rate of addiction. The addicts are students, professionals, businessmen, laborers, rickshaw/van pullers and from other professionals. Students are most affected and drugs have caused deterioration of academic performance and students have also given-up going to schools and colleges. These addicts are turning into various criminal activities in order to procure drugs. The present study was carried out to assess the present situation and identify the impact of drug addiction on social environment.

\section{MATERIALS AND METHODS}

The study was conducted through personal interview of 38 identified addicts respondents from ward-2 (Kristopur and Kalibari), ward-1 (Natok ghorlane and munsibari), ward-4 (Brammopolly and Purohitpara), ward-5 (Baganbari), ward-14 (Maskanda), and ward-20 (Kewatkhali) areas of Mymensingh town. Different centers for Rehabilitation of Drug Addiction in Mymensingh town were purposively selected. The selected centers were i) Punorjibon, Taltola, Mymensingh ii) SETU, Chupsha Majar area, Mymensingh iii) Aalo, Vatikasor, Mymensingh iv) Dip, Mashkanda, Dokhin Para, Mymensingh. Keeping all the objectives of study in view and considering the limitation on research with respect to time, transportation and other facilities, the study area was selected for the following reasons: a) Easily accessible to the respondents, b) Apparently a quite large number of drug addicts were available in those areas, c) Easy communication facilities, d) Willingness of the respondents to cooperate with the researcher. In order to collect relevant information from the respondents, three sets of interview schedule were used. The schedules were carefully designed in keeping the objectives of the study in view. The schedule contained very easy, simple, direct questions and different scales were used to obtain information. Direct questions were used to obtain information on age, level of education, family information etc. The interview schedule was pre-tested by interviewing five sampled drug addicted and then final shape was given to the interview schedule.

Data were collected by the researcher himself during June to October 2009. Data were collected through direct personal interview by the researcher himself among drug addicts, affected people in the locality and with the authority of rehab centers as per schedule designed during study period. To get actual and valid information from them, all possible effort were made to explain the purpose of the study and assured the respondents about the confidentiality of the information. After completing each interview, the schedule was checked and verified to be sure that answer to each item listed in it had been properly recorded. A discussion was held with the local elite to seek their opinions on eradication of drug addiction from the society. The collected data were analyzed by the SPSS (Statistical Package for Social Science) program, using cross tab to find out the $\%$ of total data, mean, standard deviation and correlation between two or more variables. 


\section{RESULTS AND DISCUSSION}

Three types of respondents from different wards of Mymensingh town were surveyed to find their perception about the impact of drug addiction on social environment. The types of respondents are: Drug addicted respondents, local people who were affected by drug addiction, personnel of rehabilitation centre.

\section{Age of respondents}

Thirty eight drug addicts were interviewed in this study. Among the respondents about half of them were aged more than thirty years. About two-fourth people were aged between 25 to 30 years and another twofourth people were aged less than 25 years. Rupon (2009) reported less than 30 years respondents were mostly addicted to drugs. In this study he also found that most drug addicts were more than 30 years of age. This difference has occurred due to difference of respondents as well as study area.

\section{Marital status of drug addicted respondents}

Survey result showed that more than 60 percent respondents were unmarried and around 40 percent respondents were.

\section{Occupation and Education of respondents}

Among the respondents more than 30 percent were students. About $18 \%$ drug addicted were daily labourers and unemployed people each. About 8 percent drugs addicted were businessmen and service holders. Approximately 13 percent people were involved in other occupation (Table 1).

Survey results reported that about 30 percent addicted were illiterate. More than 25 percent people were educated upto SSC level. About 18 percent respondents had completed graduation. Around 13 percent people were educated upto HSC level. Only 10 percent people were educated upto primary level (Table 1). Wright (2001) reported illiterate people were mostly addicted to drugs. Result of this study found similar where both literate and illiterate peoples were addicted.

Table 1. Occupational and Educational status of drug addicted respondents in the study area

\begin{tabular}{|llll|}
\hline Occupation & Percent (\%) & Education & Percent (\%) \\
\hline Student & 34.2 & Illiterate & 31.6 \\
Unemployed & 18.4 & Upto Primary & 10.5 \\
Businessman & 7.9 & Upto SSC & 26.3 \\
Labourers & 18.4 & Upto HSC & 13.2 \\
Service holders & 7.9 & Graduate & 18.4 \\
Others & 13.2 & - & - \\
\hline
\end{tabular}

\section{Sources of drugs}

Survey result showed more than half of the addicts got their drugs from their friends. More than one-fourth respondents purchased their drugs from the dealers. Only 5 percent and 7 percent respondents got their dope from the local leaders and local drug sellers (Table 2).

\section{Variation of drugs}

Survey result showed that more than half of the respondents used alcohol and more than one-fourth of the respondents used aba. On the other hand only 13 percent and 5 percent respondents used gaza and syrup respectively (Table 2 ).

Table 2. Source and Variety of drugs according to drug addicted respondents

\begin{tabular}{|llll|}
\hline Source of drugs & Percent (\%) & Variety of drugs & Percent (\%) \\
\hline Friends & 57.9 & Alcohol & 55.3 \\
Dealers & 28.9 & Gaza & 13.2 \\
Local Leader & 5.3 & Yaba & 26.3 \\
Local drug seller & 7.9 & Syrup & 5.3 \\
\hline
\end{tabular}




\section{Place and time of using drugs}

Survey result revealed that among the respondents nearly one-third people used drugs at river side. Nearly one-fifth people used drugs in home and at road side. More than 10 percent respondents used drugs in student mess and in park. Only about 7 percent people took drugs in rail station. It is evident in this study that maximum addicted used drugs at the old Bharmaputra river side.

Survey result revealed, about 55 percent respondents used drugs at day time and around 34 percent respondents used drugs at night. Only about 10 percent respondents used drugs occasionally (Table 3 ).

Vender (2011) reported that the most of the respondents used drugs at both day and night time. But this study revealed that most of the respondents used drugs at day time.

Table 3. Time of using drugs according to respondents

\begin{tabular}{|ll|}
\hline Time & Percent (\%) \\
\hline Night & 34.2 \\
Day & 55.3 \\
Occasionally (Eid, Puja) & 10.5 \\
Total & 100.0 \\
\hline
\end{tabular}

\section{Respondents influence on others about drugs}

Survey result revealed that over 90 percent respondents discouraged others to take drugs and only about 7 percent respondents encouraged others to take drugs. Drug addicts realized themselves that drug addiction is very harmful for human health. So, they discouraged others to take drugs.

\section{Side effect of using drugs}

Researcher found that nearly 37 percent respondents suffered side effects like vommiting and nearly 30 percent respondents suffered from vertigo. About 15 percent respondents experienced headache and gastric. Only around 18 percent respondents experienced all the symptoms (Table 4).

Table 4. Side effect of taking drugs

\begin{tabular}{|ll|}
\hline Side effects & Percent (\%) \\
\hline Vomiting & 36.8 \\
Vertigo & 28.9 \\
Headache \& Gastric & 15.8 \\
All Symptom & 18.4 \\
\hline
\end{tabular}

\section{Local people who are affected by drug addiction}

Survey result showed that among the affected local resident nearly half of the respondents were grocery shopkeeper. Nearly one third respondents were confectionary worker and only about 18 percent respondents were tea stall owner (Table 5).

Grocery shopkeepers were mostly sufferer because the addicts often took items from their shop by force and didn't pay the money. The shop owner could not do anything because they were afraid of the addicts.

Table 5. Occupation of the affected people in the study area

\begin{tabular}{|ll|}
\hline Occupation & Percent (\%) \\
\hline Grocery shopkeeper & 45.5 \\
Tea stall owner & 18.2 \\
Confectionary worker & 36.4 \\
\hline
\end{tabular}




\section{Presence of drug business in the study area}

Survey result showed that there was drug business in more than 80 percent study area and in around 18 percent of study area there was no drug business. So, it is evident that there was existence of drug business in the most of study area. Presence of drug business deteriorates the disciplinary condition of the locality.

\section{Socio-Economic condition of the drug dealer}

Survey result showed, more than 40 percent drug dealers were poor. About 27 percent drug dealer were very poor. More than 15 percent dealers were from middle class (according to author's observation) and only around 9 percent drug dealer were rich.

\section{Causes of drug addiction}

Survey result showed, nearly two-third people thought that depression was the main cause of drug addiction. More than one-fourth people told that friends' inspiration was a cause of drug addiction and only around 9 percent people became drug addicted from curiosity.

\section{Source of money of the addicted people}

Survey result showed more than half of the respondents admitted that stealing was the main source of money of the drug addicts. Less than one-third people told robbery and only around 18 percent told that hijacking was the source of money of addicted people in the locality (Table 6). Criminal activities like robbery, hijacking and stealing are worsening social environment in the study area.

Table 6. Distribution of Source of income of the addicted people

\begin{tabular}{|ll|}
\hline Source & Percent (\%) \\
\hline Robbery & 18.2 \\
Hijacking & 27.3 \\
Stealing & 54.5 \\
\hline
\end{tabular}

\section{Police and social activity against drug addiction}

Survey result showed that more than 70 percent people said that there was policing to control drug business in the locality but this was not enough to control the drug business. More than 70 percent people said that there was no local activity against drug dealing. Although people were suffering from drug business they didn't protest against it, because the drug suppliers were connected with the powerful people of the society and the general people were afraid of them.

\section{Numbers of patients admitted in rehab centre (Dip)}

Survey result showed that average 204 addicts were admitted in this rehab centre per year in which 36.85 were students, 33.04 were unemployed, 14.93 were businessman, 3.52 were labourer, nearly 6 were service holder and about 6 were from other occupation where number of students was remarkable and increasing the number of addicted day by day.

\section{Numbers of patients came round from rehab centre}

Rehab centre DIP offered for a treatment of 3 months. According to the record of DIP, nearly 45 addicts were completely, about 33 were moderately and 22.29 were cured to lower extent from 2008 to 2012. Average numbers of cured patients were reported 182 per year.

\section{Relationship between occupation and drug addiction}

The relationship between occupation of the respondents and drug addiction was examined by testing the null hypothesis: "There is no relationship between occupation of the respondents and drug addiction". The computed value of the co-efficient of correlation between occupation and drug addiction was found to be 0.537 shown in table 7. Based on the co-efficient value, the following observations were made: The relationship showed a positive trend. A significant relationship was found between two variables at 0.01 level of probability. Occupation is significant on drug addiction. More busy person like service holders are rarely drug addicted but students are easily get involved with drugs. Based on the above findings, the null hypothesis was rejected. 


\section{Relationship between marital status and drug addiction}

The relationship between marital status of the respondents and drug addiction was examined by testing the null hypothesis: "there is no relationship between marital status and drug addiction". The computed value of the co-efficient of correlation between marital status and drug addiction was found to be 0.512 shown in Table 7. Based on the co-efficient value, the following observations were made: The relationship showed a positive trend. A significant relationship was found between two variables at 0.01 level of probability. Marital status is significant on drug addiction. Married people are less addicted to drugs. Based on the above findings, the null hypothesis was rejected.

Table 7. Relationship between Drug Addiction and other selected characteristics $(\mathrm{N}=38)$

\begin{tabular}{|llll|}
\hline $\begin{array}{l}\text { Dependent } \\
\text { variable }\end{array}$ & Independent variable & Computed value of ' $r$ ' & Level of significant (\%) \\
\hline \multirow{3}{*}{ Drug Addiction } & Occupation & $0.537^{* *}$ & \\
& Marital status & $0.512^{* *}$ & 0.01 \\
& Category of family & $0.739^{* *}$ & \\
\hline
\end{tabular}

${ }^{* *}$ Correlation is significant at the 0.01 level (2-tailed)

\section{Relationship between education of the respondents and drug addiction}

The relationship between education of the respondents and drug addiction was examined by testing the null hypothesis: "there is no relationship between education of the respondents and drug addiction". The computed value of the co-efficient of correlation between education and drug addiction was found to be 0.671 as shown in table 7 . Based on the co-efficient value, the following observations were made (Table 7). The relationship showed a negative trend. A significant negative relationship was found between to variables at 0.01 level of probability. Educational qualification is significant on drug addiction. Based on the above findings, the null hypothesis was rejected.

\section{CONCLUSION}

The study was carried out through personal interview of 38 identified drug addicted from different wards and different rehabilitation centers for drug addiction in Mymensingh town. The drug addictants were selected with the help of local people. Some of them were also drug addicts and the people associated with illegal drug business and some of them were selected in the study were the patients under treatments in different Centers for Rehabilitation of Drug Addiction in Mymensingh town. Local residents who had indirectly affected by drug addicted were also interviewed. It was found that drugs make a person passionate about it which resulted in physical and mental disorder and cause several diseases. Due to their behavioral changes they commit hijacking, extortion, stealing, and robbery activities. It is a matter of great concern for Mymensingh where among the addicted people most of them are young. Now, not only Mymensingh, it is a burning question for the nation, because of spoiling of golden aged people is hampered our social life and finally national progress. For safety of society and a developed nation, every person must be aware about the bad effect of drug addiction on individuals, family and also as a burden in the country. If it is tried to check drug addiction in only Mymensingh town, it would not be fruitful, because Mymensingh is not a disconnected area of country. Therefore, considerable measures should be undertaken throughout country. In view of the study, following recommendation can be considered to rescue the society from drug addiction: 1. Drug addiction, its bad effects and preventive measures should be included in school curriculum. 2. Family members, particularly father, mother should play key roll to check this hazardous menace from their family. 3 . Law enforcing agencies should be patrolled in respective entry of all banned drugs in the country, identification and stepping be seriously dealt with. 4 . Community participation should be ensured to find out the treatment, rehabilitation and in prevention the spread of drug addiction problem. 


\section{REFERENCES}

1. Amin ZA, 2007. Just say no. Dhaka: The Daily Star, $15^{\text {th }}$ July.

2. Dip, 2010. Annual statistics on drug addiction. DIP, Mymensingh, pp. 1-5.

3. Ikfat M, 2007. Effect of drug addiction on physical capabilities of rural and urban youth. MS Thesis, The Department of Environmental Science, Bangladesh Agricultural University, Mymensingh, P. 53.

4. Ray R, 1998. Current extent and pattern of drug abuse. In: Ray R, editor. Drug demand reduction report. New Delhi: UNDCP Regional Office for South Asia.

5. Reid G, G Costigan, 2002. Revisiting 'the hidden epidemic' a situation assessment of drug use in Asia in the context of HIVIAIDS. Victoria: Centre for harm reduction. The Burnet Institute.

6. Rupan GK, 2009. Impact of drugs on human health and social environment. MS Thesis, Department of Environmental Science, BAU, pp. 27-36.

7. United Nations Office on Drug and Crime (UNODC) 2003. South Asia: regional profile. New Delhi: UNODC Regional Office for South Asia.

8. Vander VT, 2011. Getting Wasted: Why College Students Drink Too Much and Party So Hard. New York, NY: New York University Press.

9. Wright S, H Klee, 2001. Violent Crime, Aggression and Amphetamine: What Are the Implications for Drug Treatment Services? Drugs: Educ. Prev. Policy, 8: 73-90. 